\title{
Emersion and Relative Humidity Modulate Stress Response and Recovery Dynamics in Juvenile Mussels (Perna canaliculus)
}

\author{
Natalí J. Delorme ${ }^{1, *}$, David J. Burritt ${ }^{2}$, Norman L. C. Ragg ${ }^{1}\left(\mathbb{D}\right.$ and Paul M. South ${ }^{1}$ \\ 1 Cawthron Institute, Private Bag 2, Nelson 7042, New Zealand; norman.ragg@cawthron.org.nz (N.L.C.R.); \\ paul.south@cawthron.org.nz (P.M.S.) \\ 2 Department of Botany, University of Otago, P.O. Box 56, Dunedin 9054, New Zealand; \\ david.burritt@otago.ac.nz \\ * Correspondence: natali.delorme@cawthron.org.nz; Tel.: +64-036-687-755
}

check for updates

Citation: Delorme, N.J.; Burritt, D.J.; Ragg, N.L.C.; South, P.M. Emersion and Relative Humidity Modulate Stress Response and Recovery Dynamics in Juvenile Mussels (Perna canaliculus). Metabolites 2021, 11, 580. https://doi.org/10.3390/

metabo11090580

Academic Editors: Pierre Blier and Hélène Lemieux

Received: 20 July 2021

Accepted: 24 August 2021

Published: 27 August 2021

Publisher's Note: MDPI stays neutral with regard to jurisdictional claims in published maps and institutional affiliations.

Copyright: (c) 2021 by the authors. Licensee MDPI, Basel, Switzerland. This article is an open access article distributed under the terms and conditions of the Creative Commons Attribution (CC BY) license (https:/ / creativecommons.org/licenses/by/ $4.0 /)$.

\begin{abstract}
The early stages of intertidal mussels, including the green-lipped mussel, Perna canaliculus, face both direct and indirect environmental threats. Stressors may influence physiological status and, ultimately, survival. An understanding of the nature of stress experienced is critical to inform conservation and aquaculture efforts. Here, we investigated oxidative stress dynamics in juvenile P. canaliculus in relation to emersion duration (1-20 h) and relative humidity ( $\mathrm{RH}, 29-98 \%)$ by quantifying oxidative damage (protein carbonyls, lipid hydroperoxides, 8-hydroxydeoxyguanosine) and enzymatic antioxidants (superoxide dismutase, catalase, glutathione peroxidase and reductase). Mussels held in low RH during emersion experienced severe water loss ( $>70 \%)$, high mortality (>80\%) and increased oxidative damage (35-45\% increase compared to control conditions), while mussels held at high RH were not impacted, even after $20 \mathrm{~h}$ of air exposure. Following re-immersion, reoxygenation stress resulted in further increases in damage markers in mussels that had experienced dryer emersion conditions; protective action of antioxidants increased steadily during the $10 \mathrm{~h}$ re-immersion period, apparently supporting a reduction in damage markers after $1-5 \mathrm{~h}$ of immersion. Clearly, conditions during emersion, as well as duration, substantially influence physiological performance and recovery of juvenile mussels. Successful recruitment to intertidal beds or survival in commercial aquaculture operations may be mediated by the nature of emersion stress experienced by these vulnerable juveniles.
\end{abstract}

Keywords: green-lipped mussel; Greenshell ${ }^{\mathrm{TM}}$ mussel; Perna canaliculus; spat; emersion; oxidative stress; reoxygenation stress; recovery; survival

\section{Introduction}

Emersion is a significant source of stress for marine organisms. During emersion, organisms can be exposed to fluctuations in temperature, irradiance, and relative humidity (RH), with many intertidal organisms having physiological and behavioural adaptions that allow them to cope with such stressors [1,2]. For example, mussels can tolerate heat exposure and prevent desiccation by modifying their gaping behaviour, metabolism, and respiration [3-7]. The capacity to tolerate emersion in marine invertebrates closely relates to their bathymetric distribution [8,9]. Some bivalve molluscs depress their metabolism during emersion [10] or rely on anaerobic pathways to maintain ATP production for short emersion periods [11,12]; air-gaping during long-term emersion exposure may subsequently assist in acid-base regulation [13]. These different strategies to deal with emersion-related hypoxia are then likely to affect the organism's responses following re-immersion in seawater.

Immersion in seawater after an emersion period is critical for the recovery and survival of the organism but is itself a stressor due to the oxidative damage caused to macromolecules (lipids, proteins and DNA) by rapid reoxygenation of the cells and the accumulation of free radicals and reactive oxygen species (ROS) in the cells $[14,15]$. ROS are produced in the cell through normal metabolism, and in molluscs they represent around 
$1-3 \%$ of the consumed oxygen [16]. ROS are neutralised by enzymatic and non-enzymatic antioxidants [17]; however, under stressful conditions, levels/activities of cellular antioxidants can be too low to cope with the production of ROS, resulting in oxidative damage and, ultimately, cell death $[14,15,17]$. Due to physical limitations to oxygen uptake during periods of air exposure, emersion often does not result in an immediate increased in oxidative damage [18]. However, the oxygenation of haemolymph in bivalves that had previously experienced emersion increased rapidly within the first hour of re-immersion in seawater [19]. This reoxygenation can result in a significant increase in ROS formation in bivalves, together with significant changes in oxidative damage and antioxidant levels/activities [20-23]. To date, most studies of the effects of emersion and recovery in marine bivalves have focused on adults [18-23]. Such effects possibly vary among life stages due to ontogenetic differences in metabolism, respiration, and behaviour, although few studies have reported emersion- and recovery-induced stress responses in juvenile marine invertebrates, e.g., [24,25].

Juvenile mytilid mussels ('spat') may be particularly vulnerable to the repercussions of emersion and reoxygenation stress. Settling juveniles typically colonise substrates free of adult mussels [26], which may reflect an area that is particularly affected by the stressors associated with emersion. Mussel spat also retain the capacity to resume pelagic drifting by the production of a mucus 'parachute', facilitating relocation but elevating the risk of predation [27]. It has been suggested that environmental stress may influence the resumption of pelagic drifting [28], and hence indirectly affect subsequent survival. The present study evaluated the stress response and recovery dynamics of juvenile, greenlipped mussels, Perna canaliculus, which is also an important aquaculture species in New Zealand $[29,30]$. The mussel industry routinely transfers juvenile mussels from their capture sites or from its single hatchery to marine farms around the country, a process that can involve emersion of up to $72 \mathrm{~h}[29,31]$. Previous studies have described the stress response of $P$. canaliculus juveniles and adults to fasting, heat and simulated transport, showing that fasted juveniles are less able to tolerate subsequent stress, and that transport results in oxidative damage [32-34]. Additionally, variations in RH during emersion can affect the resettlement behaviour of juvenile $P$. canaliculus during recovery in seawater, although the underlying dynamic of physiological responses of these stressed juveniles remains unknown [28]. Therefore, the aim of this study was to assess the interactive effects of variations in emersion duration and $\mathrm{RH}$ on the stress responses and recovery dynamics of juvenile $P$. canaliculus during immersion in seawater. Stress responses were measured by quantifying oxidative damage (protein carbonyls, lipid hydroperoxides, 8-hydroxydeoxyguanosine) and enzymatic antioxidants (superoxide dismutase, catalase, glutathione peroxidase and reductase), as well as the water content and survival of the juvenile mussels. These parameters were evaluated experimentally in the laboratory to test the hypothesis that longer emersion times in a dryer environment would affect metabolism, stress levels, condition and recovery dynamics of juvenile $P$. canaliculus.

\section{Results}

\subsection{Emersion Conditions}

During emersion, relative humidity ( $\mathrm{RH}$ ) was consistently above $90 \%$ for the high $\mathrm{RH}$ treatment, with an average RH of $98 \pm 2 \%$ (SD, $n=242$; Figure 1A). In contrast, RH for low and mid RH treatments was more variable. Low and mid RH treatments started at approximately 15 and $60 \%$, respectively, but average values over $20 \mathrm{~h}$ were, respectively, $29 \pm 5 \%$ and $82 \pm 11 \%$ (SD, $n=242$ for each mean; Figure $1 \mathrm{~A}$ ). RH in the low RH treatment was $16 \pm 2 \%$ during the first hour of emersion, increasing to $22 \pm 4 \%$ after $5 \mathrm{~h}$ of emersion and then to a maximum value of around $32 \%$ by the end of the $20 \mathrm{~h}$ of emersion (Figure 1B). $\mathrm{RH}$ in the mid RH treatment was $61 \pm 1 \%$ during the first hour of emersion and increased to $67 \pm 4 \%$ after $5 \mathrm{~h}$ of emersion, before reaching a maximum value of around $94 \%$ by the end of the $20 \mathrm{~h}$ emersion period (Figure 1B). 

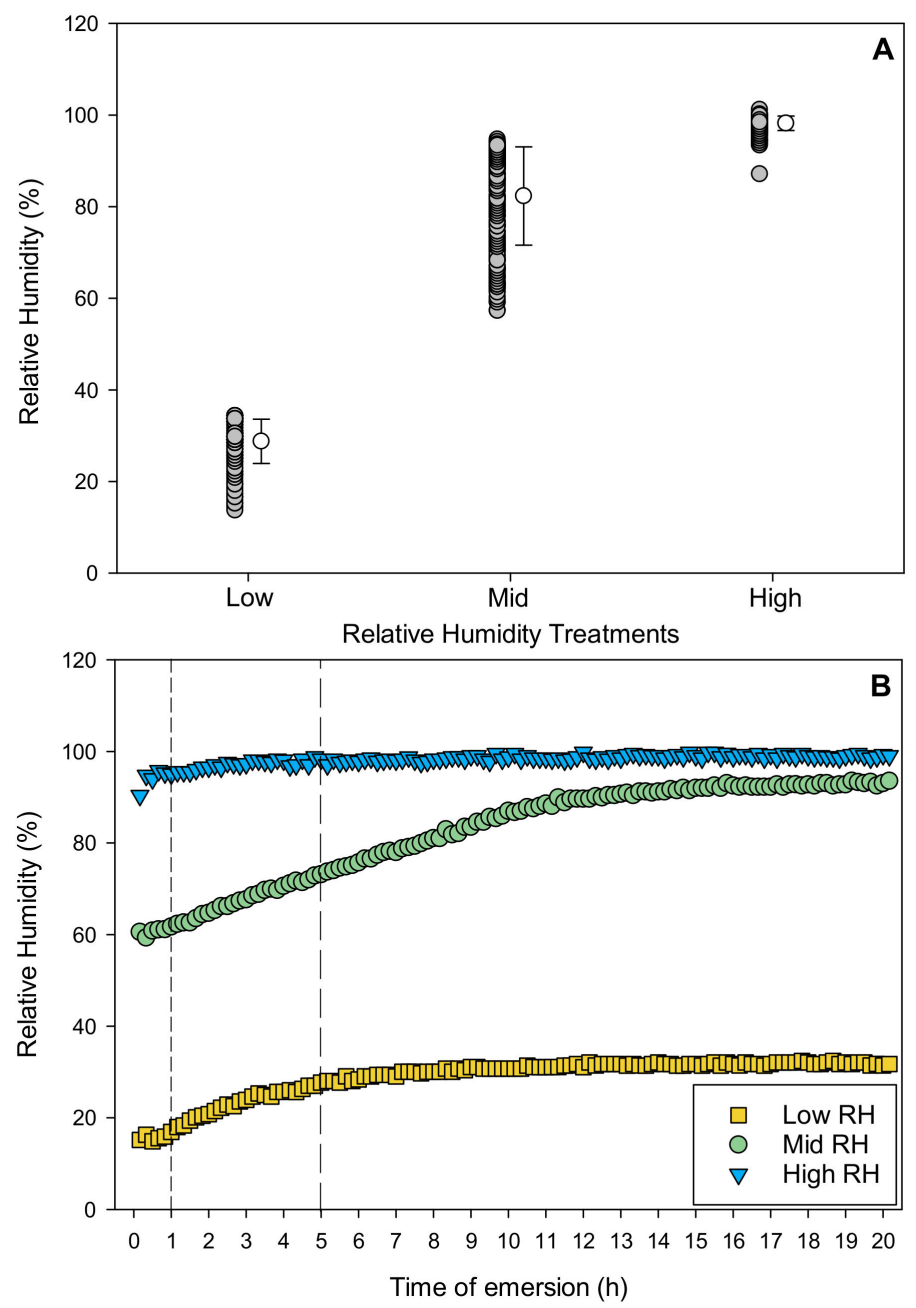

Figure 1. Relative humidity $\left(\mathrm{RH}, \% ; 18^{\circ} \mathrm{C}\right)$ during emersion in treatments. (A): Plot showing data for each RH treatment (low, mid and high) and their respective means \pm standard deviation (SD, $n=242$ ). (B): Time series for each of $\mathrm{RH}$ treatment during $20 \mathrm{~h}$ of emersion (average of two loggers per treatment, $10 \mathrm{~min}$ sample interval). Short and long dashed lines show the end points of the $1 \mathrm{~h}$ and $5 \mathrm{~h}$ emersion treatments, respectively.

\subsection{Water Content}

The water content of the juvenile mussels was reduced by increasing emersion time and decreasing RH (Figure 2, Table 1). In the high RH treatment, water content was consistently high at around $68-75 \%$ across emersion treatments (Figure 2). The water content of mussels maintained at mid $\mathrm{RH}$ was high $(\sim 70 \%)$ and showed no change during the first $5 \mathrm{~h}$ of emersion, but then decreased to around $12 \%$ after $20 \mathrm{~h}$ of emersion (Figure 2). The water content of the juveniles in the low RH treatment decreased over time and was lower than the mid and high RH treatments after 1 and $5 \mathrm{~h}$ emersions (Figure 2). After $20 \mathrm{~h}$ of emersion, the water content of juveniles in the low and mid RH treatments was similar, with water content being between $8-12 \%$ (Figure 2). 


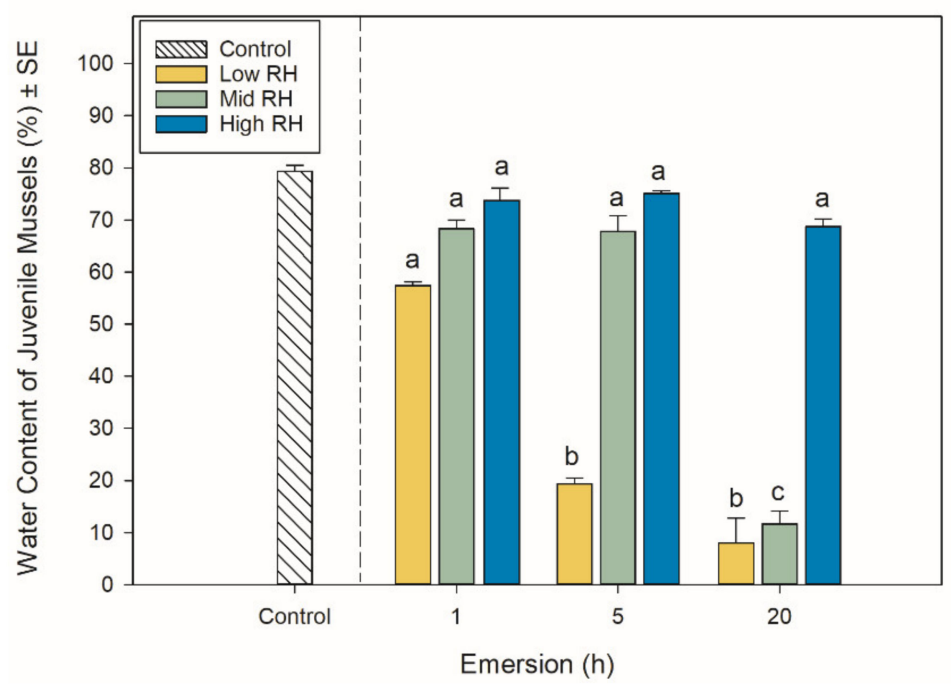

Figure 2. Water content ( $\%$ live mass $\pm \mathrm{SE}, n=3$ ) in juvenile Perna canaliculus exposed to different relative humidity ( $\mathrm{RH}$; low, mid, high) and emersion $(1,5,20 \mathrm{~h})$ treatments. Control bar indicates water content in juveniles that were not emersed (excluded from statistical analysis). Tukey pair-wise comparisons show significant differences $(p<0.05)$ for the interaction between emersion time and relative humidity treatments, which are denoted by different lower-case letters above bars.

Table 1. ANOVA results of water content, mortality and staining percentage data for Perna canaliculus juveniles in different relative humidity (RH) treatments during emersion (E: 1, 5 and $20 \mathrm{~h}$ ), followed by recovery in seawater (R: 1, 5 and $10 \mathrm{~h}$ ). Degrees of freedom (df), mean square (MS), F-ratio and $p$-values are shown for each variable. Significant results $(p<0.05)$ are shown in bold.

\begin{tabular}{ccccc}
\hline Water Content & df & MS & F & $p$ \\
\hline Relative Humidity (RH) & 2 & 0.565 & 32.785 & $<\mathbf{0 . 0 0 1}$ \\
Emersion time (E) & 2 & 0.276 & 16.023 & $<\mathbf{0 . 0 0 1}$ \\
RH $\times$ E & 4 & 0.077 & 4.515 & $\mathbf{0 . 0 1 1}$ \\
Residual & 18 & 0.017 & & \\
\hline Estimated Mortality & df & MS & F & $p$ \\
\hline Relative Humidity (RH) & 2 & 4.436 & 422.941 & $<\mathbf{0 . 0 0 1}$ \\
Emersion time (E) & 2 & 7.987 & 761.58 & $<\mathbf{0 . 0 0 1}$ \\
RH $\times$ E & 6 & 1.663 & 158.529 & $<\mathbf{0 . 0 0 1}$ \\
Residual (between-effects) & 36 & 0.01 & & \\
Recovery time (R) & 2 & 0.776 & 159.186 & $<\mathbf{0 . 0 0 1}$ \\
RH $\times$ R & 4 & 1.662 & 30.832 & $<\mathbf{0 . 0 0 1}$ \\
R $\times$ E & 4 & 0.15 & 35.811 & $<\mathbf{0 . 0 0 1}$ \\
RH $\times$ R $\times$ E & 8 & 0.061 & 12.422 & $<\mathbf{0 . 0 0 1}$ \\
Residual (within-effects) & 72 & 0.005 & & $\boldsymbol{p}$ \\
\hline Staining & df & MS & F & $<\mathbf{0 . 0 0 1}$ \\
Relative Humidity (RH) & 2 & 2.142 & 246.423 & $<\mathbf{0 . 0 1}$ \\
Emersion time (E) & 2 & 1.454 & 167.251 & $<\mathbf{0 . 0 1}$ \\
RH $\times$ E & 4 & 0.209 & 24.026 & \\
Residual & 36 & 0.009 & & \\
\hline
\end{tabular}

\subsection{Mortality Estimates: Observations and Staining}

Observational live/dead assessments indicated interactive effects of emersion time, $\mathrm{RH}$ and recovery time on estimates of mortality that increased with time of emersion, especially in the low and mid RH treatments (Figure 3, Table 1). The effect of recovery time varied among emersion and $\mathrm{RH}$ treatments with the percentage of estimated dead mussels increasing over time in the low and mid RH treatments (Figure 3). Few juveniles that were emersed for $1 \mathrm{~h}$ or held at high $\mathrm{RH}$ appeared to die during this experiment (Figure 3). At 
the end of the experiment, $0.5 \pm 0.32 \%(\mathrm{SE}, n=5)$ of juvenile mussels were estimated to be dead in control samples.

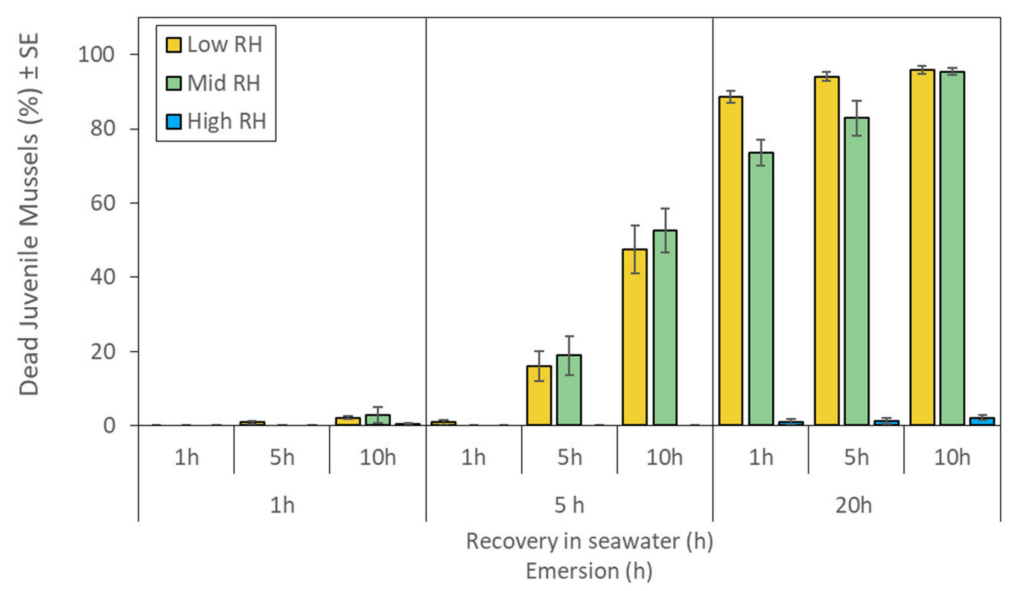

Figure 3. Estimates of mortality in juvenile Perna canaliculus exposed to different relative humidity (RH; low, mid, high) and emersion (1, 5, $20 \mathrm{~h}$ ) treatments, followed by recovery in seawater $(1,5,10 \mathrm{~h})$. Data represent mean percent of dead juveniles \pm standard error $(\mathrm{SE}, n=5)$.

Fast Green staining in control mussels was apparent in $11 \pm 1.6 \%(\mathrm{SE}, n=5)$ of individuals. The percentage of stained mussels increased with emersion time, with the greatest percentage occurring in mussels exposed to $20 \mathrm{~h}$ of emersion (Figure 4). A smaller percentage of juveniles stained in high $\mathrm{RH}$ treatments at all emersion durations relative to the mid and low RH treatments (Figure 4). Low and mid RH treatments had similar effects on the percentage of stained juveniles within each of the 1 and $5 \mathrm{~h}$ emersion treatments (Figure 4). After $20 \mathrm{~h}$ of emersion, there were fewer mussels stained in the mid RH treatment compared to the low RH treatment, but the percentage stained in these treatments was $84 \%$ greater than in the high RH treatment (Figure 4).

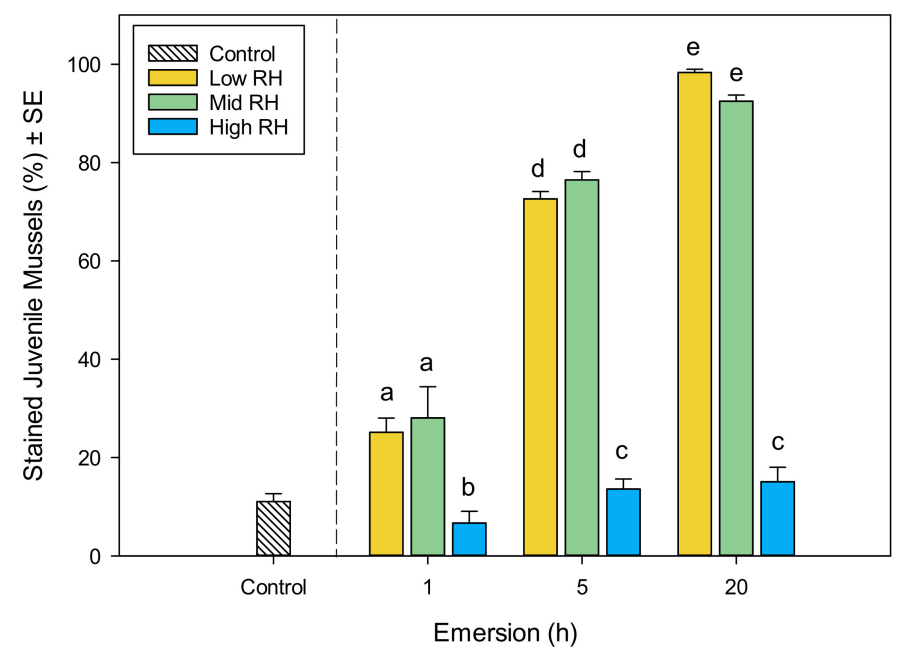

Figure 4. Fast Green staining of juvenile Perna canaliculus exposed to different relative humidity (RH; low, mid, high) and emersion $(1,5,20 \mathrm{~h})$ treatments, followed by $10 \mathrm{~h}$ recovery in seawater. Control bar shows percentage of stained mussels that were continuously immersed in flowing seawater (excluded from statistical analysis). Data represent the mean percent of stained mussels \pm standard error (SE, $n=5)$. Tukey pair-wise comparisons show significant differences $(p<0.05)$ for the interaction between emersion time and relative humidity treatments, which are denoted by different lower-case letters above bars. 


\subsection{Oxidative Damage}

There were interactive effects of emersion time, $\mathrm{RH}$ treatment and recovery time on levels of protein carbonyls (PCs), lipid hydroperoxides (LPs) and DNA damage, measured as 8-OHdG, in juvenile mussels (Table 2).

Table 2. ANOVA results of oxidative damage biomarkers data for Perna canaliculus juveniles exposed to different relative humidity $(\mathrm{RH})$ treatments during emersion (E: 1, 5 and $20 \mathrm{~h}$ ), followed by recovery in seawater (R: 0, 1, 5 and $10 \mathrm{~h})$. Significant results $(p<0.05)$ are shown in bold.

\begin{tabular}{|c|c|c|c|c|}
\hline Protein Carbonyls (PCs) & df & MS & $\mathbf{F}$ & $p$ \\
\hline Relative Humidity (RH) & 2 & $1.8^{-2}$ & 86.5 & $<0.001$ \\
\hline Emersion time $(\mathrm{E})$ & 2 & $1.4^{-2}$ & 68.2 & $<0.001$ \\
\hline Recovery time (R) & 3 & $3.4^{-3}$ & 16.6 & $<0.001$ \\
\hline $\mathrm{RH} \times \mathrm{E}$ & 4 & $1.9^{-3}$ & 9.2 & $<0.001$ \\
\hline $\mathrm{RH} \times \mathrm{R}$ & 6 & $1.8^{-4}$ & 0.8 & 0.541 \\
\hline $\mathrm{E} \times \mathrm{R}$ & 6 & $3.5^{-4}$ & 1.7 & 0.137 \\
\hline $\mathrm{RH} \times \mathrm{E} \times \mathrm{R}$ & 12 & $7.3^{-4}$ & 3.5 & $<0.001$ \\
\hline Residual & 72 & $2.1^{-4}$ & & \\
\hline Lipid Hydroperoxides (LPs) & df & MS & $\mathbf{F}$ & $p$ \\
\hline Relative Humidity (RH) & 2 & 2026.9 & 87.2 & $<0.001$ \\
\hline Emersion time $(\mathrm{E})$ & 2 & 2281 & 98.1 & $<0.001$ \\
\hline Recovery time (R) & 3 & 1371.2 & 59 & $<0.001$ \\
\hline $\mathrm{RH} \times \mathrm{E}$ & 4 & 521.8 & 22.4 & $<0.001$ \\
\hline $\mathrm{RH} \times \mathrm{R}$ & 6 & 151.4 & 6.5 & $<0.001$ \\
\hline $\mathrm{E} \times \mathrm{R}$ & 6 & 175 & 7.5 & $<0.001$ \\
\hline $\mathrm{RH} \times \mathrm{E} \times \mathrm{R}$ & 12 & 62.4 & 2.7 & 0.005 \\
\hline Residual & 72 & 23.3 & & \\
\hline DNA Damage (8-OHdG) & df & MS & $\mathbf{F}$ & $p$ \\
\hline Relative Humidity (RH) & 2 & 4206.1 & 125.8 & $<0.001$ \\
\hline Emersion time (E) & 2 & 6239.2 & 186.6 & $<0.001$ \\
\hline Recovery time (R) & 3 & 1055.1 & 31.6 & $<0.001$ \\
\hline $\mathrm{RH} \times \mathrm{E}$ & 4 & 2001.9 & 59.9 & $<0.001$ \\
\hline $\mathrm{RH} \times \mathrm{R}$ & 6 & 277.5 & 8.3 & $<0.001$ \\
\hline $\mathrm{E} \times \mathrm{R}$ & 6 & 80.1 & 2.4 & 0.036 \\
\hline $\mathrm{RH} \times \mathrm{E} \times \mathrm{R}$ & 12 & 198.6 & 5.9 & $<0.001$ \\
\hline Residual & 72 & 33.5 & & \\
\hline
\end{tabular}

There were strong effects of emersion and recovery duration on PCs levels in all but the high RH treatment (Figure 5A, Table 2). After $1 \mathrm{~h}$ of emersion, levels of PCs were higher for the low and mid RH treatments (relative to high $\mathrm{RH}$ ) after $1 \mathrm{~h}$ of recovery, which declined to similar levels to those observed in high RH after 5 and $10 \mathrm{~h}$ of recovery (Figure 5A). After $5 \mathrm{~h}$ of emersion, levels of PCs in the low and mid RH treatments were significantly elevated after 0,1 and $5 \mathrm{~h}$ of recovery, but then declined in the mid $\mathrm{RH}$ treatment to levels approaching baseline after $10 \mathrm{~h}$ of recovery (Figure 5A). An emersion time of $20 \mathrm{~h}$ caused a more substantial increase in PCs levels in the low and mid RH treatments; these were sustained over $10 \mathrm{~h}$ of recovery, while PCs levels in the high RH treatment remained at basal levels (Figure 5A). The low RH treatment generally induced greater and more variable PCs levels compared to mid and high RH (Figure 5A).

Levels of lipid hydroperoxides (LPs) were generally greater in mussels in the low and mid RH treatments, rapidly rising during the first hour of re-immersion to maximum levels that increased in correlation with emersion time (Figure 5B, Table 2). LP levels subsequently decreased with increasing time of recovery, approaching baseline after $10 \mathrm{~h}$, except for mussels exposed to $20 \mathrm{~h}$ of emersion at low $\mathrm{RH}$, where LP levels remained significantly elevated (Figure 5B). 

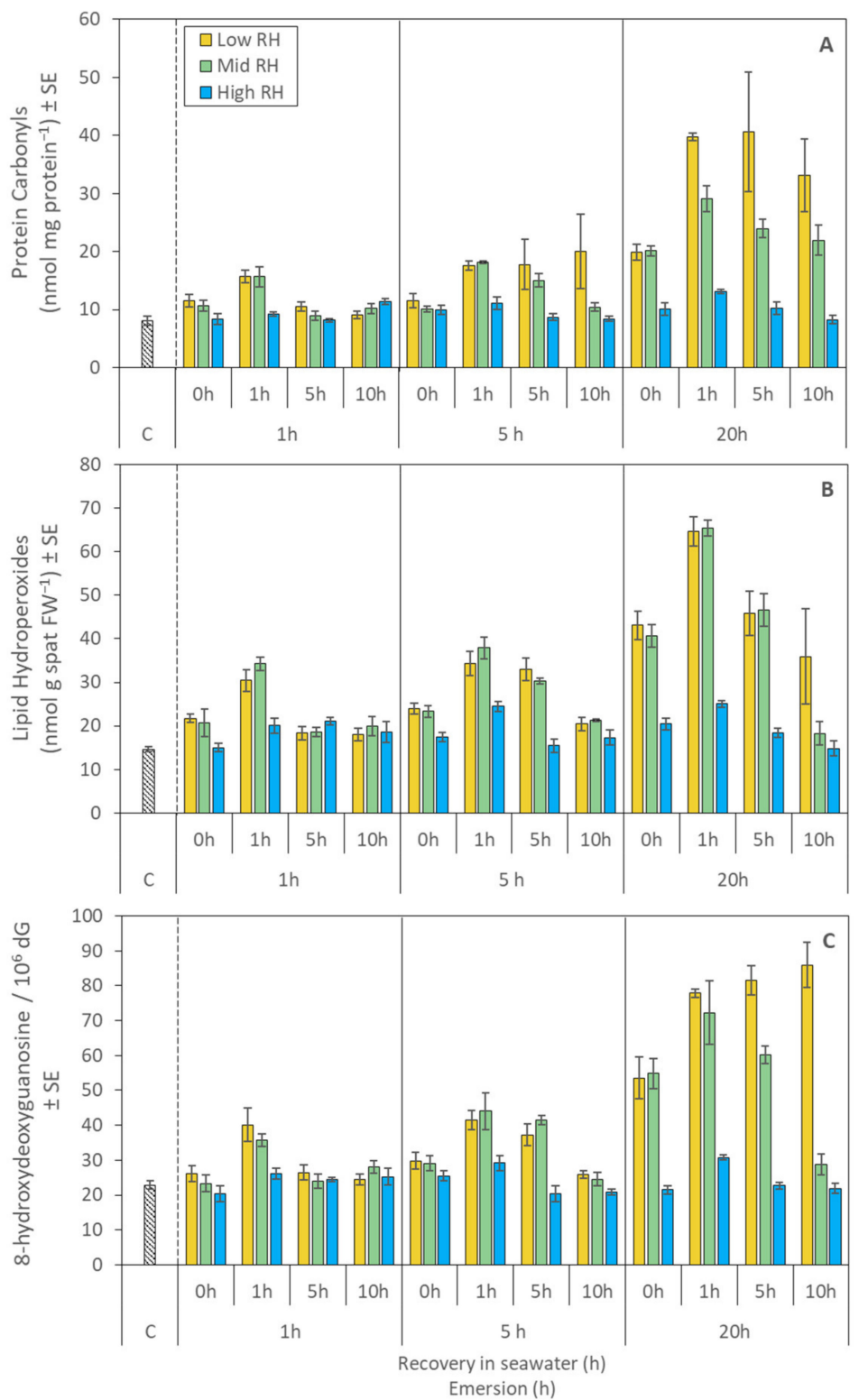

Figure 5. Oxidative damage biomarkers in juvenile Perna canaliculus exposed to different relative humidity (RH; low, mid, high) and emersion $(1,5,20 \mathrm{~h}$ ) treatments, followed by recovery in seawater $(0,1,5,10 \mathrm{~h})$. Control bar (c) shows biomarker concentration in mussels that were continuously immersed in flowing seawater (excluded from statistical analysis). (A): Protein carbonyls (PCs); (B): Lipid hydroperoxides (LPs); (C): 8-hydroxydeoxyguanosine (8-OHdG). Data are mean concentration \pm standard error (SE, $n=3$ ).

There were similar patterns for 8-OHdG levels with a general trend of increased 8 -OHdG levels in mussels after $1 \mathrm{~h}$ of recovery in seawater (Figure 5C, Table 2). An exception for this measure of DNA damage was that $8-\mathrm{OHdG}$ continued to increase in the low $\mathrm{RH} / 20$-h emersion treatment during recovery, in part driving a strong interaction among the experimental factors (Figure 5C, Table 2).

\subsection{Enzymatic Antioxidants}

Enzymatic antioxidant activity was similar in all mussels sampled at the end of emersion, regardless of duration and $\mathrm{RH}$ treatment, resembling levels in control animals (Figure 6 A-D, Table 3). Activity consistently increased with recovery in seawater in low and mid RH treatments after 1 and $5 \mathrm{~h}$ of emersion, and in mid RH treatment after $20 \mathrm{~h}$ 
of emersion, driving $\mathrm{RH} \times$ recovery interactions for all analyses (Figure $6 \mathrm{~A}-\mathrm{D}$, Table 3). Activity of enzymatic antioxidants for mussels from the high RH treatment remained at baseline levels during recovery, regardless of emersion duration (Figure $6 \mathrm{~A}-\mathrm{D}$ ).
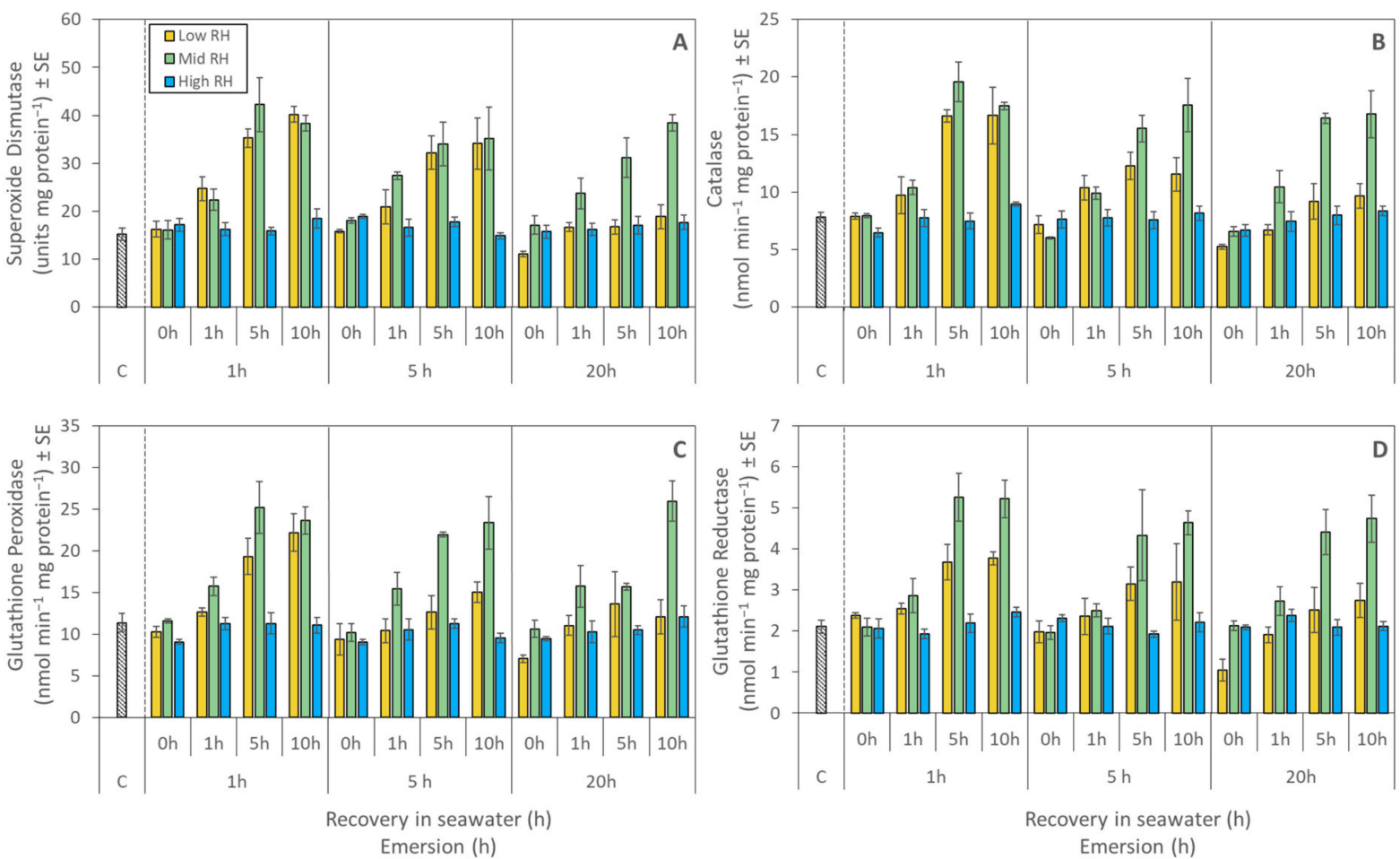

Figure 6. Antioxidant biomarker activity in juvenile Perna canaliculus exposed to different relative humidity (RH; low, mid, high) and emersion (1, 5, $20 \mathrm{~h}$ ) treatments, followed by recovery in seawater $(0,1,5,10 \mathrm{~h})$. Control bar (c) shows biomarker activity in mussels that were continuously immersed in flowing seawater (excluded from statistical analysis). (A): Superoxide Dismutase (SOD); (B): Catalase (CAT); (C): Glutathione Peroxidase (GPx); (D): Glutathione Reductase (GR). Data are mean concentrations \pm standard error $(\mathrm{SE}, n=3)$.

Table 3. ANOVA results of enzymatic antioxidant biomarkers data for Perna canaliculus juveniles exposed to different relative humidity (RH) treatments during emersion (E: 1, 5 and $20 \mathrm{~h}$ ), followed by recovery in seawater (R: 0, 1, 5 and $10 \mathrm{~h})$. Significant results $(p<0.05)$ are shown in bold.

\begin{tabular}{ccccc}
\hline Superoxide Dismutase (SOD) & df & MS & F & $p$ \\
\hline Relative Humidity (RH) & 2 & 1260.5 & 62.2 & $<\mathbf{0 . 0 0 1}$ \\
Emersion time (E) & 2 & 262.4 & 12.9 & $<\mathbf{0 . 0 0 1}$ \\
Recovery time (R) & 3 & 873.7 & 43.1 & $<\mathbf{0 . 0 0 1}$ \\
RH $\times$ E & 4 & 161.5 & 8 & $<\mathbf{0 . 0 1}$ \\
RH $\times$ R & 6 & 232.8 & 11.5 & $<\mathbf{0 . 0 0 1}$ \\
E $\times$ R & 6 & 36.2 & 1.8 & 0.115 \\
RH $\times$ E $\times$ R & 12 & 31.7 & 1.6 & 0.123 \\
Residual & 72 & 20.3 & & \\
Catalase (CAT) & df & MS & F & p \\
Relative Humidity (RH) & 2 & 243.5 & 72.7 & $<\mathbf{0 . 0 0 1}$ \\
Emersion time (E) & 2 & 41 & 12.2 & $<\mathbf{0 . 0 0 1}$ \\
Recovery time (R) & 3 & 223.8 & 66.8 & $<\mathbf{0 . 0 0 1}$ \\
RH $\times$ E & 4 & 21.6 & 6.4 & $<\mathbf{0 . 0 0 1}$ \\
RH $\times$ R & 6 & 49.6 & 14.8 & $<\mathbf{0 . 0 0 1}$ \\
E $\times$ R & 6 & 4.5 & 1.4 & 0.248 \\
RH $\times$ E $\times$ R & 12 & 3.2 & 1 & 0.487 \\
Residual & 72 & 3.4 & & \\
\hline
\end{tabular}


Table 3. Cont.

\begin{tabular}{ccccc}
\hline Glutathione Peroxidase (GPx) & df & MS & F & $p$ \\
\hline Relative Humidity (RH) & 2 & 521 & 66.4 & $<\mathbf{0 . 0 0 1}$ \\
Emersion time (E) & 2 & 61.6 & 7.9 & $<\mathbf{0 . 0 0 1}$ \\
Recovery time (R) & 3 & 308.2 & 39.3 & $<\mathbf{0 . 0 0 1}$ \\
RH $\times$ E & 4 & 21.9 & 2.8 & $\mathbf{0 . 0 3 3}$ \\
RH $\times$ R & 6 & 62.2 & 8 & $<0.001$ \\
E $\times$ R & 6 & 10.7 & 1.4 & 0.239 \\
RH F E $\times$ R & 12 & 13.1 & 1.7 & 0.092 \\
Residual & 72 & 7.8 & & \\
\hline Glutathione Reductase (GR) & df & MS & F & $p$ \\
\hline Relative Humidity (RH) & 2 & 18.9 & 42.5 & $<\mathbf{0 . 0 0 1}$ \\
Emersion time (E) & 2 & 2 & 4.5 & $\mathbf{0 . 0 1 5}$ \\
Recovery time (R) & 3 & 13.2 & 29.8 & $<\mathbf{0 . 0 0 1}$ \\
RH $\times$ E & 4 & 1 & 2.3 & 0.067 \\
RH $\times$ R & 6 & 4.4 & 9.8 & $<\mathbf{0 . 0 0 1}$ \\
E $\times$ R & 6 & 0.2 & 0.5 & 0.811 \\
RH $\times$ E $\times$ R & 12 & 0.1 & 0.1 & 1 \\
Residual & 72 & 0.5 & & \\
\hline
\end{tabular}

\section{Discussion}

This study showed that the effects of emersion and the re-immersion dynamics of juvenile Perna canaliculus are complex and mainly depend on the conditions that the mussels experience during emersion. Juvenile mussels that experienced longer emersion at low and mid relative humidity $(\sim 15-60 \% \mathrm{RH})$ had increased water loss, increased oxidative damage and antioxidant enzymatic activity. These elevated levels, however, only tended to become apparent following re-immersion. The accumulation of oxidative damage in juvenile $P$. canaliculus, despite a corresponding increase in antioxidant activity, was correlated to increasing mortality rates during the $10 \mathrm{~h}$ re-immersion monitoring period (up to $\sim 95 \%$ following $20 \mathrm{~h}$ emersion at low-mid $\mathrm{RH}$ ). This correlation between emersion time, oxidative damage, and mortality was tested for all oxidative stress markers at the different $\mathrm{RH}$ levels at the end of the recovery time (see Supplementary Materials). The strongest correlation was observed for oxidative damage in the form of PCs at low and mid RH, where mortality increased steadily with PC levels, as time of emersion increased $\left(r^{2}=0.9991\right.$ at low RH and $r^{2}=0.7273$ at mid RH). LPs and DNA damage also correlated to mortality observations only at low $\mathrm{RH}$, but these correlations were weaker $\left(r^{2}=0.8630\right.$ and $r^{2}=0.7844$ for LPs and DNA damage, respectively). This suggests that mussels that experience emersion at low $\mathrm{RH}$ are most likely to die due to oxidative stress, whereas oxidative damage is reduced at mid $\mathrm{RH}$ probably due to the specific action of antioxidants. At mid RH, it is likely that mussels were not dead but compromised, widely gaping and unable to close their valves after emersion and RH stress and are therefore classified as "dead". Surviving mussels could also be physiologically impaired due to the high oxidative damage, potentially resulting in altered biological functions or even further mortality with increasing immersion time.

Green-lipped mussels naturally colonise rocks of the lower littoral and sub-tidal zones of New Zealand [35]. The emersion times used in this study are representative of a typical exposure period for an intertidal P. canaliculus $(1 \mathrm{~h})$, an exceptional low tide event $(5 \mathrm{~h})$, and an artificial emersion time which would represent a common transport time for mussel spat from hatchery to the grow-out farms $(20 \mathrm{~h})$. It should be noted that the juvenile mussels used in this study are hatchery produced from subtidal mussel populations (farmed); the results shown here might vary from the potential stress response of wild spat which may have previously experienced emersion [36] and associated stressors, with the potential to either increase [37] or reduce [32] subsequent stress tolerance.

Emersion of juvenile $P$. canaliculus caused severe water loss when RH was lower during emersion, and with increasing exposure times. Mussels isolate their soft tissues 
from the external environment by closing their valves during emersion, using periodic gaping behaviour to decrease their body temperature and facilitate gas exchange, allowing adult mussels to withstand long periods of emersion $[4,6,38]$. However, few studies have assessed the role of gaping in juvenile mussels. In the present study, there were two lines of evidence to suggest that juvenile P. canaliculus used gaping behaviour as a mechanism to reduce stress during emersion. First, there was a significant decrease in the water content of emersed juveniles that was exacerbated as emersion duration increased. Second, the mid humidity treatment showed increasing $\mathrm{RH}$ with the time of emersion, indicating that moisture from the mussels was released into the container during incubation. Even though $\mathrm{RH}$ increased in the mid RH treatment to levels ca. $80 \%$, mussels experienced increased oxidative damage and antioxidant activity during the subsequent re-immersion period, compared to mussels held in high RH during emersion. This suggests that desiccation stress could also play a crucial role in the recovery dynamics of P. canaliculus.

It can be challenging to determine whether juvenile mussels are dead, moribund or alive using visual observations [28,39]. Here, our estimates suggested that mortality increased with recovery time, especially in the more severe RH treatments, with no differences between mid and low $\mathrm{RH}$ treatments at the end of the $10 \mathrm{~h}$ recovery period. Following $20 \mathrm{~h}$ emersion and low or mid $\mathrm{RH}$, for example, $>90 \%$ of individuals subsequently appeared unresponsive in water and took up Fast Green stain. However, measures of antioxidant enzyme activities suggest that these mussels were still metabolically active in the mid treatment. Indeed, given the substantial increases in antioxidant enzyme activities over the $10 \mathrm{~h}$ immersion period, it seems likely that many of these mussels were alive, but moribund and unable to respond to tactile stimulus or an osmotic shock (i.e., valve closure when immersed in freshwater and stain). This hypothesis could be tested with extended immersion periods to determine whether these mussels completely recover. By contrast, the high RH appears relatively benign, even when spat are emersed for $20 \mathrm{~h}$, with most mussels showing signs of life or the ability to respond to tactile or osmotic stimulus and are therefore more likely to remain viable [39].

Marine littoral organisms experiencing natural emersion due to tidal cycles can accumulate modest levels of ROS during air exposure as they shift to anaerobic metabolism [17,40]. Despite demonstrating net metabolic depression [41], many enzymatic antioxidants are activated during the emersion period as a preparation for the reoxygenation stress ("preparation for oxidative stress", POS) [42-44]. When organisms are immersed in the water for recovery, reoxygenation of haemolymph occurs rapidly (within one hour) [19], causing an oxidative burst, and the generation of large amounts of ROS [43]. In invertebrates, the oxidative burst is less intense and happens more slowly than in vertebrates; nonetheless, the excessive production of ROS can still result in oxidative damage [45]. In this study, juvenile P. canaliculus exposed to low and mid humidity air showed increased oxidative damage after $20 \mathrm{~h}$ of emersion compared to control mussels that remained submersed in seawater. Here, $P$. canaliculus experienced a more extreme emersion stress than most intertidal species as they moved from a completely subtidal environment to an extreme emersion period $(20 \mathrm{~h})$. However, oxidative stress was minimised if mussels were maintained in high humidity during emersion, where damage levels were similar to non-emersed control mussels. Reoxygenation has been shown to increase oxidative damage in the mussel Mytilus edulis [20], the gastropod Crepipatella dilatata [46], and the oyster Crassostrea virginica [47]. In the present study, reoxygenation stress resulted in a rapid increase in oxidative damage markers in all the humidity treatments, but levels were significantly higher following low and mid humidity exposure during emersion. Oxidative damage in the mussels that were exposed to high humidity during a $20 \mathrm{~h}$ emersion showed a decrease in damage to baseline levels after the mussels had been in seawater for $10 \mathrm{~h}$.

Antioxidant enzyme activity in juvenile $P$. canaliculus did not increase during the emersion period at any humidity level. This suggests that juvenile $P$. canaliculus may have a reduced POS (i.e., preparation for oxidative stress) capacity to cope with reoxygenation stress during recovery, as seen in other invertebrate species [43]. In adults of the brown 
mussel, Perna perna, emersion stress for $48 \mathrm{~h}$ lowered the activity of enzymatic antioxidants; however, the levels of the non-enzymatic antioxidant glutathione (GSH) showed a rapid and persistent increase during emersion [48]. In the mussel Mytilus edulis, 48 and $72 \mathrm{~h}$ anoxia in seawater had little effect on the activity of antioxidants; however, antioxidant activity was suppressed after $72 \mathrm{~h}$ anoxia followed by $24 \mathrm{~h}$ of reoxygenation [20]. In the present study, there was an increase in enzymatic antioxidant activity of juvenile $P$. canaliculus in all treatments following re-immersion, which agrees with similar findings in other invertebrate species [46,49-51]. Levels of antioxidant activity in mussels held in high humidity conditions during emersion returned to baseline levels after $10 \mathrm{~h}$ of recovery. In contrast, mussels held at mid humidity during emersion showed no indication of declining after $10 \mathrm{~h}$ in seawater. It should be noted that mussels held at low humidity during emersion typically displayed low levels of antioxidant activity, similar to mussels that were held at high humidity. However, this result is likely to be an artifact of the high mortality of the mussels in the low humidity treatment, associated with high oxidative damage in the mussels sampled, but low antioxidant activity which is likely to have come from the small proportion of live mussels.

In this study, the increased action of antioxidants observed after short emersion periods ( 1 and $5 \mathrm{~h}$ ) helped maintain relatively low levels of oxidative damage at all $\mathrm{RH}$ levels after re-immersion. However, at longer emersion $(20 \mathrm{~h})$, the activity of some antioxidants becomes compromised, resulting in an accumulation of oxidative damage in the tissues.

Emersion can be an occasional or regular event for juvenile P. canaliculus. For example, $P$. canaliculus can be an intertidal organism that experiences semidiurnal low tides, or they can be occasionally cast ashore while attached to drift algae. Juvenile P. canaliculus are also routinely emersed to transfer them to sea-based nursery farms for aquaculture, a process that can take as long as 3 days and be highly variable in terms of environmental conditions [52]. Losses of juvenile P. canaliculus after they are seeded onto a marine farm are a common problem for the mussel industry in New Zealand, where most of the juveniles are lost during the first few months of aquaculture [53-56]. Based on the results of the present study, it is possible that conditions in which the juvenile mussels are transported trigger a series of molecular, biochemical and physiological responses in the mussels that could have carry-over effects for the mussels after seeding, potentially affecting retention and survival of the juveniles. For example, juvenile resettlement behaviour was slowed and reduced by lower RH conditions during emersion [28]. The data presented here suggest that such impacts on behaviour could correspond to the physiological condition of the juveniles which, in the case of juveniles emersed in drier conditions, reflect increased ROS damage and antioxidant activity.

Complex, multi-species mussel guilds occupy the New Zealand rocky shore, with lower-littoral Perna canaliculus giving way to Mytilus, Aulacomya and Xenostrobus species on the higher shore $[35,57]$. Thermotolerance has been demonstrated to be a key determinant of this vertical zonation [57], which is turn likely to be influenced by region, latitude and genetic structure [58]. Based on the findings presented here, it would be valuable to consider the role of juvenile emersion and, in particular, reoxygenation stress as factors influencing natural distribution in an increasingly marine heatwave-prone region [59].

Overall, the present study showed that juvenile $P$. canaliculus are extremely sensitive to low humidity and prolonged emersion times, with mussels held in low RH during emersion experiencing severe water loss, high oxidative damage and high mortality, while mussels held at high RH were not impacted, even after $20 \mathrm{~h}$ of air exposure. These findings have significant implications for natural shoreline distribution and the aquaculture industry where juvenile mussels are routinely emersed during the production cycle. For aquaculturists, transportation methods should aim to maintain mussels in a high humidity environment at a constant temperature for the shortest possible time to mitigate the deleterious effects described in this study. When the time of emersion cannot be shortened, mussels should be held in a high relative humidity environment to minimise the stress responses elicited in the juvenile mussels, including increased oxidative damage 
and subsequent mortality. Further research is required to unravel the complex factors influencing resilience and environmental stress in the juveniles that appear to represent a major life-stage bottleneck for both cultured and wild P. canaliculus populations.

\section{Materials and Methods}

\subsection{Experimental Design}

Green-lipped mussel juveniles ( $\sim \mathrm{mm})$ were collected from a commercial hatchery (SPATnz) and transported to the laboratory of the adjacent Cawthron Aquaculture Park (Nelson, New Zealand). Mussels were weighed and separated into 178 circular sieves $(8 \mathrm{~cm}$ diameter, $200 \mu \mathrm{m}$ mesh size). Separate sets of experimental sieves were allocated for the determination of water content (27 sieves; $120 \mathrm{mg}$ of mussels in each sieve), assessments of survival (50 sieves; $10 \mathrm{mg}$ of mussels in each sieve) and oxidative biomarker analysis (111 sieves; $1 \mathrm{~g}$ of mussels in each sieve). The sieves were then placed in a shallow acclimation tank with flowing seawater at $18{ }^{\circ} \mathrm{C}$ containing a mixture of axenically cultured microalgae (Chaetoceros calcitrans, C. muelleri and Pavlova lutheri). All sieves were supplied with food ad libitum during the first $24 \mathrm{~h}$ after collection before experimentation.

Experimental treatments consisted of three relative humidity $(\mathrm{RH})$ treatments (low $=\sim 15 \%$, $\mathrm{mid}=\sim 60 \%$, and high $=\sim 90 \%$ ), four emersion times $(0,1,5$ and $20 \mathrm{~h}$ ) and three recovery times $(1,5$ and $10 \mathrm{~h}$ ) following re-immersion in seawater. Control mussels were not emersed during the experiment. Replication consisted of three replicated sieves per treatment for oxidative damage and antioxidant biomarker analyses, three replicated sieves for water content analysis, and five replicated sieves for survival. Lowered RH levels were achieved by adding different amounts of desiccant (silica gel) to a circular, $750 \mathrm{~mL}$ air-tight plastic container; for the high $\mathrm{RH}$ treatment, a seawater-saturated cotton cloth was added to the containers. Following acclimation, the experimental sieves with mussels were blot-dried and randomly allocated to the different $\mathrm{RH}$ treatments. All containers were tightly closed immediately after addition of the experimental sieves and placed in an incubator at $18{ }^{\circ} \mathrm{C}$. RH loggers (Hygrochrons, iButtonLink Technology, Whitewater, WI, USA) sampling at $10 \mathrm{~min}$ intervals were added to 6 of the containers allocated to $20 \mathrm{~h}$ of emersion (two per RH treatment). After each of the emersion treatments, the mussels in the sieves were either sampled, assessed as described below, or randomly assigned to re-immersion treatments.

\subsection{Water Content and Mortality Estimates}

Water content in juvenile mussels was determined as percent mass loss by weighing (wet), drying (at $100^{\circ} \mathrm{C}$ for $24 \mathrm{~h}$ ), and re-weighing.

Sieves allocated to survival monitoring were surveyed repeatedly throughout the re-immersion recovery period. A stereomicroscope was used to observe the immersed mussels; wide-open individuals that did not respond to a tactile stimulus (prodding with forceps) were considered to be dead [25].

After the last recovery time point $(10 \mathrm{~h})$, mussels were stained using the Fast Green method [39], with minor modifications, to provide an indication of viability. In brief, mussels were transferred from the experimental sieves into freshwater $(\sim 20 \mathrm{~mL})$ in $35 \mathrm{~mL}$ plastic containers to induce valve closure. One drop of concentrated Fast Green dye was added to each container, and the mussels were left in the stain for $1 \mathrm{~h}$. Individuals that were incapable of sustained valve closure throughout this period were considered inviable (dead or moribund) and took up dye; the green-stained tissues of these spat could subsequently be discerned through the translucent valves. The mussels were subsequently rinsed and frozen at $-20^{\circ} \mathrm{C}$. Samples were thawed and mussels were counted; the percentage of stained individuals per sample was calculated and used as the response variable in analyses.

\subsection{Oxidative Damage}

Juvenile mussels were sampled for oxidative biomarker analyses before emersion (control), directly after the completion of the emersion periods ( $0 \mathrm{~h}$ recovery) or after 1,5 or $10 \mathrm{~h}$ of recovery in seawater. Three sub-samples of $\sim 130-140 \mathrm{mg}$ of juvenile mussels 
(fresh weight) were taken from each of the replicate sieves for each assay. Each subsample was placed into $2 \mathrm{~mL}$ cryo-vials, flash frozen in liquid nitrogen and stored at $-80^{\circ} \mathrm{C}$ until analyses. The sub-samples were used to determine oxidative damage (protein carbonyls (PCs), lipid hydroperoxides (LPs) and 8-hydroxydeoxyguanosine (8-OHdG)) and antioxidant enzyme activity (superoxide dismutase (SOD), catalase (CAT), glutathione peroxidase (GPx) and glutathione reductase (GR)).

\subsubsection{Macromolecule Extraction}

Macromolecule extractions (protein, lipid and DNA) for determination of oxidative damage in juvenile P. canaliculus were performed according to Delorme et al. [32] In brief, total protein was extracted on ice by adding $900 \mu \mathrm{L}$ of ice-cold enzyme extraction buffer (100 mM potassium phosphate [pH 7.5] containing $50 \mathrm{mM} \mathrm{NaCl}, 0.1 \mathrm{mM} \mathrm{Na} 2 \mathrm{EDTA}, 1 \%$ polyvinylpyrrolidone-40, $2 \mathrm{mM}$ phenylmethylsulfonyl fluoride and $0.1 \%$ TritonX-100) and homogenising for $30 \mathrm{~s}$ at $1500 \mathrm{rpm}\left(1600 \mathrm{MiniG}^{\circledR}, \mathrm{SPEX}^{\circledR}\right)$ using zirconia/silica beads and a pre-chilled cryo-block $\left(\mathrm{SPEX}^{\circledR}\right)$. The samples were then centrifuged for $15 \mathrm{~min}$ at $17,000 \times g$ at $4{ }^{\circ} \mathrm{C}$ and the supernatant (i.e., protein extract) purified using ultrafiltration and purification columns (AMICON). The purified protein extract was then washed and reconstituted with $250 \mu \mathrm{L}$ of $50 \mathrm{mM}$ potassium phosphate buffer ( $\mathrm{pH}$ 7.2), placed in a $1.5 \mathrm{~mL}$ microcentrifuge tube, blown with oxygen-free nitrogen and stored at $-80{ }^{\circ} \mathrm{C}$. Protein content was determined by the Lowry protein assay [60]. Samples were diluted with potassium phosphate as required before analysis. The levels of protein carbonyls (PCs) were determined via reaction with 2.4-dinitrophenylhydrazine (DNPH) as described by Reznick and Packer [61] and expressed as nmols of carbonyls mg of protein ${ }^{-1}$.

Total lipids were extracted by adding $600 \mu \mathrm{L}$ of methanol:chloroform $(2: 1 v / v)$ and homogenised as described above. The homogenised sample was left to stand for $5 \mathrm{~min}$ and an extra $400 \mu \mathrm{L}$ of chloroform were added and vortexed vigorously for $30 \mathrm{~s}$. Then, $400 \mu \mathrm{L}$ of MilliQ water were added and the sample vortexed again for $30 \mathrm{~s}$. The samples were then centrifuged at an ambient temperature for $30 \mathrm{~s}$ at 17,000 $\times \mathrm{g}$. Finally, the chloroform phase (bottom layer) was removed and transferred to a clean $1.5 \mathrm{~mL}$ microcentrifuge tube, blown with oxygen-free nitrogen and stored at $-80^{\circ} \mathrm{C}$ until analysis. The level of lipid hydroperoxides (LPs) in the samples was determined by absorbance at $500 \mathrm{~nm}$ using the ferric thiocyanate method described by Mihaljevic et al. [62], adapted for measurement in a microtitre plate reader. A calibration curve with t-butyl hydroperoxide was used and the LP content calculated as nmol of lipid hydroperoxide per mg of fresh (wet) mussel weight.

PC and LP assays were carried out using a Victor 1420 Multilabel plate reader (Perkin Elmer Wallac, Waltham, MA, USA) fitted with a temperature control cell (set to $25^{\circ} \mathrm{C}$ ) and an auto-dispenser. Data were acquired and processed using the WorkOut 2.0 software package (Perkin Elmer, Waltham, MA, USA).

DNA extraction was performed using an ISOLATE II Genomic DNA Kit (Bioline, Memphis, TN, USA), with one minor modification-the samples were crushed and homogenised using a tube pestle after the addition of the pre-lysis buffer. The final DNA extracts were placed in a $1.5 \mathrm{~mL}$ microcentrifuge tube, blown with oxygen-free nitrogen and stored at $-80^{\circ} \mathrm{C}$ until analyses. The level of oxidised DNA was calculated by quantifying the amount of 8-hydroxydeoxyguanosine (8-OHdG) present using high-performance liquid chromatography (HPLC) followed by UV detection of guanine and electrochemical detection (coulometric) of 8-OHdG as described previously for P. canaliculus juveniles [32].

\subsubsection{Enzymatic Antioxidants}

The remaining protein extract was used to perform antioxidant enzyme assays: superoxide dismutase activity (SOD), catalase (CAT), glutathione peroxidase (GPx) and glutathione reductase (GR) as described by Delorme et al. [32] In brief, SOD was determined using a Cayman Chemicals Superoxide Dismutase Assay Kit and the activity expressed as units of SOD mg of protein ${ }^{-1}$. CAT was assayed using the chemiluminescent method of Maral et al. [63], as adapted by Janssens et al. [64] for 96-well microplates, and 
the activity expressed as $\mu \mathrm{mol} \mathrm{min}^{-1} \mathrm{mg}$ protein ${ }^{-1}$. GPx activity was measured according to the spectrophotometric method described by Paglia and Valentine [65] and expressed as nmol min $^{-1} \mathrm{mg}$ of protein ${ }^{-1}$. GR was assayed using the method of Cribb et al. [66], with minor modifications and activity expressed as nmol $\mathrm{min}^{-1} \mathrm{mg}$ of protein ${ }^{-1}$. All enzymatic assays were carried out using a Perkin Elmer Wallac Victor 1420 multilabel counter (Perkin Elmer, Waltham, MA, USA) as detailed above.

\subsection{Statistical Analyses}

All analyses were carried out using analysis of variance (ANOVA) with $\alpha=0.05$ unless otherwise stated. Assumptions of ANOVA were checked using appropriate tests (ShapiroWilk, Brown Forsythe, Mauchly) and graphical observations. Water content, mortality and staining percentage data were arcsine-square root transformed prior to analysis. Water content data were not normally distributed but met the assumption of homoscedasticity and were analysed using a two-way ANOVA with RH level and emersion time as factors since balanced ANOVA is robust to deviations from normality [67]. Estimates of mortality data were analysed using a repeated measures ANOVA with RH and emersion time as the between-subjects effects, and re-immersion time as the within-subjects effect to account for repeated observations of individual sieves. Estimated mortality data were non-normal and variances were heterogeneous but met the assumption of sphericity and were analysed with $\alpha=0.01$ [68]. Staining data were analysed using a two-way ANOVA $(\alpha=0.01)$, with $\mathrm{RH}$ level and emersion time as fixed factors. All oxidative damage (PCs, LPs, 8-OHdG) and enzymatic antioxidants (SOD, CAT, GPx, GR) data were analysed with three-way ANOVA using RH, emersion time, and recovery time as fixed factors. PC data did not meet parametric assumptions and were transformed to the reciprocal before analysis. Differences among treatments were identified using Tukey pair-wise tests with $\alpha=0.05$. Analyses were carried out using Sigma Plot 14.0 (SYSTAT Software, Inc., Chicago, IL, USA) or Statistica 12 (Statsoft) software.

Supplementary Materials: The following are available online at https:/ /www.mdpi.com/article/ 10.3390/metabo11090580/s1, Figure S1: Correlations between oxidative damage and mortality observations after $10 \mathrm{~h}$ of recovery in seawater. A: Protein carbonyls (PCs); B: Lipid hydroperoxides (LPs); C: 8-hydroxydeoxyguanosine (8-OHdG; DNA damage). Data from different emersion times were combined to plot oxidative damage versus mortality across emersion time for each relative humidity (RH) treatment, Figure S2: Correlations between oxidative damage and mussel staining after $10 \mathrm{~h}$ of recovery in seawater. A: Protein carbonyls (PCs); B: Lipid hydroperoxides (LPs); C: 8-hydroxydeoxyguanosine (8-OHdG; DNA damage). Data from different emersion times were combined to plot oxidative damage versus staining across emersion time for each relative humidity (RH) treatment.

Author Contributions: Conceptualization, N.J.D. and P.M.S.; methodology, N.J.D. and P.M.S.; formal analysis, N.J.D. and P.M.S.; investigation, N.J.D. and P.M.S.; resources, D.J.B.; writing-original draft preparation, N.J.D.; writing—review and editing, N.J.D., D.J.B., N.L.C.R. and P.M.S.; visualization, N.J.D. and P.M.S.; project administration, N.L.C.R. All authors have read and agreed to the published version of the manuscript.

Funding: This research was funded by the New Zealand Ministry for Business, Innovation and Employment, through the Cawthron Shellfish Aquaculture Platform, Contract No. CAWX1801.

Institutional Review Board Statement: No ethical approval was required for this study. According to the New Zealand Animal Welfare Act, ethical approval for work using molluscs is not needed (except for cephalopods).

Informed Consent Statement: Not applicable.

Data Availability Statement: The data presented in this study are available on request from the corresponding author. The data are not publicly available due to the value of researchers' interaction when/if the data are requested. 
Acknowledgments: We thank SPATnz for supplying mussel spat, and to Leonardo Zamora, Jessica Ericson, Karthiga Kumanan, Jolene Berry, Joanna Copedo and Bridget Finnie for their technical support and advice. Special thanks to Leonardo Zamora and Joanna Copedo for helping with designing and producing the graphic abstract.

Conflicts of Interest: The authors declare no conflict of interest.

\section{References}

1. Tomanek, L.; Helmuth, B. Physiological ecology of rocky intertidal organisms: A synergy of concepts. Integr. Comp. Biol. 2002, 42, 771-775. [CrossRef] [PubMed]

2. Helmuth, B.S.; Hofmann, G.E. Microhabitats, thermal heterogeneity, and patterns of physiological stress in the rocky intertidal zone. Biol. Bull. 2001, 201, 374-384. [CrossRef] [PubMed]

3. Nicastro, K.R.; Zardi, G.I.; McQuaid, C.D.; Stephens, L.; Radloff, S.; Blatch, G.L. The role of gaping behaviour in habitat partitioning between coexisting intertidal mussels. BMC Ecol. 2010, 10, 17. [CrossRef] [PubMed]

4. Nicastro, K.R.; Zardi, G.I.; McQuaid, C.D.; Pearson, G.A.; Serrão, E.A. Love thy neighbour: Group properties of gaping behaviour in mussel aggregations. PLoS ONE 2012, 7, e47382. [CrossRef] [PubMed]

5. Chandurvelan, R.; Marsden, I.D.; Gaw, S.; Glover, C.N. Field-to-laboratory transport protocol impacts subsequent physiological biomarker response in the marine mussel, Perna canaliculus. Comp. Biochem. Physiol. Part A 2013, 164, 84-90. [CrossRef]

6. Zamora, L.N.; Ragg, N.L.C.; Hilton, Z.; Webb, S.C.; King, N.; Adams, S. Emersion survival manipulation in Greenshell ${ }^{\mathrm{TM}}$ mussels (Perna canaliculus): Implications for the extension of live mussels' shelf-life. Aquaculture 2019, 500, 597-606. [CrossRef]

7. Dowd, W.W.; Somero, G.N. Behavior and survival of Mytilus congeners following episodes of elevated body temperature in air and seawater. J. Exp. Biol. 2013, 216, 502-514. [CrossRef]

8. Sukhotin, A.A.; Pörtner, H.O. Habitat as a factor involved in the physiological response to environmental anaerobiosis of White Sea Mytilus edulis. Mar. Ecol. Prog. Ser. 1999, 184, 149-160. [CrossRef]

9. Fernández-Reiriz, M.J.; Irisarri, J.; Labarta, U. Flexibility of physiological traits underlying inter-individual growth differences in intertidal and subtidal mussels Mytilus galloprovincialis. PLoS ONE 2016, 11, e0148245. [CrossRef] [PubMed]

10. Connor, K.M.; Gracey, A.Y. High-resolution analysis of metabolic cycles in the intertidal mussel Mytilus californianus. Am. J. Physiol. Regul. Integr. Comp. Physiol. 2012, 302, R103-R111. [CrossRef] [PubMed]

11. Hochachka, P.W.; Somero, G.N. Biochemical Adaptation: Mechanism and Process in Physiological Evolution; Oxford University Press: New York, NY, USA, 2002; p. 478.

12. Storey, K.B.; Storey, J.B. Oxygen limitation and metabolic rate depression. In Functional Metabolism: Regulation and Adaptation; Storey, K.B., Ed.; John Wiley \& Sons: Hoboken, NJ, USA, 2005; pp. 415-442.

13. Fields, P.A.; Eurich, C.; Gao, W.L.; Cela, B. Changes in protein expression in the salt marsh mussel Geukensia demissa: Evidence for a shift from anaerobic to aerobic metabolism during prolonged aerial exposure. J. Exp. Biol. 2014, 217, 1601-1612. [CrossRef] [PubMed]

14. Halliwell, B. Reactive species and antioxidants. Redox biology is a fundamental theme of aerobic life. Plant Physiol. 2006, 141, 312-322. [CrossRef] [PubMed]

15. Berg, J.M.; Tymoczko, J.L.; Gatto, G.J.; Stryer, L. Biochemistry, 9th ed.; W.H. Freeman and Company: New York, NY, USA, 2019.

16. Lewis, C.; Santos, E.M. Physiological impacts of chemical pollutants in marine animals. In Stressors in the Marine Environment; Solan, M., Whiteley, N.M., Eds.; Oxford University Press: Oxford, UK, 2016; pp. 73-92.

17. Lesser, M.P. Oxidative stress in marine environments: Biochemistry and physiological ecology. Annu. Rev. Physiol. 2006, 68, 253-278. [CrossRef]

18. Jimenez, A.G.; Alves, S.; Dallmer, J.; Njoo, E.; Roa, S.; Dowd, W.W. Acclimation to elevated emersion temperature has no effect on susceptibility to acute, heat-induced lipid peroxidation in an intertidal mussel (Mytilus californianus). Mar. Biol. 2016, 163, 55. [CrossRef]

19. Shick, J.M.; Gnaiger, E.; Widdows, J.; Bayne, B.L.; Zwaan, A.D. Activity and metabolism in the mussel Mytilus edulis L. during intertidal hypoxia and aerobic recovery. Physiol. Zool. 1986, 59, 627-642. [CrossRef]

20. Rivera-Ingraham, G.A.; Rocchetta, I.; Meyer, S.; Abele, D. Oxygen radical formation in anoxic transgression and anoxiareoxygenation: Foe or phantom? Experiments with a hypoxia tolerant bivalve. Mar. Environ. Res. 2013, 92, 110-119. [CrossRef]

21. Almeida, E.A.; Bainy, A.C.D.; Dafre, A.L.; Gomes, O.F.; Medeiros, M.H.G.; Di Mascio, P. Oxidative stress in digestive gland and gill of the brown mussel (Perna perna) exposed to air and re-submersed. J. Exp. Mar. Biol. Ecol. 2005, 318, 21-30. [CrossRef]

22. Giannetto, A.; Maisano, M.; Cappello, T.; Oliva, S.; Parrino, V.; Natalotto, A.; De Marco, G.; Fasulo, S. Effects of oxygen availability on oxidative stress biomarkers in the mediterranean mussel Mytilus galloprovincialis. Mar. Biotechnol. 2017, 19, 614-626. [CrossRef]

23. Falfushynska, H.; Piontkivska, H.; Sokolova, I.M. Effects of intermittent hypoxia on cell survival and inflammatory responses in the intertidal marine bivalves Mytilus edulis and Crassostrea gigas. J. Exp. Biol. 2020, 223, jeb217026. [CrossRef]

24. Calderwood, J.; O'Connor, N.E.; Sigwart, J.D.; Roberts, D. Determining optimal duration of seed translocation periods for benthic mussel (Mytilus edulis) cultivation using physiological and behavioural measures of stress. Aquaculture 2014, 434, 288-295. [CrossRef]

25. Jenewein, B.T.; Gosselin, L.A. Ontogenetic shift in stress tolerance thresholds of Mytilus trossulus: Effects of desiccation and heat on juvenile mortality. Mar. Ecol. Prog. Ser. 2013, 481, 147-159. [CrossRef] 
26. Alfaro, A.; Jeffs, A. Small-scale mussel settlement patterns within morphologically distinct substrata at Ninety Mile Beach, northern New Zealand. Malacologia 2002, 44, 1-15.

27. Bayne, B.L. Primary and secondary settlement in Mytilus edulis L. (Mollusca). J. Anim. Ecol. 1964, 33, 513-523. [CrossRef]

28. South, P.M.; Quirino, M.N.; LaDiega, C.; Delorme, N.J. Emersion and relative humidity control resettlement success of juvenile marine mussels. Aquaculture 2020, 529, 735675. [CrossRef]

29. Jeffs, A.G.; Delorme, N.J.; Stanley, J.; Zamora, L.N.; Sim-Smith, C. Composition of beachcast material containing green-lipped mussel (Perna canaliculus) seed harvested for aquaculture in New Zealand. Aquaculture 2018, 488, 30-38. [CrossRef]

30. Stenton-Dozey, J.M.E.; Heath, P.; Ren, J.S.; Zamora, L.N. New Zealand aquaculture industry: Research, opportunities and constraints for integrative multitrophic farming. N. Z. J. Mar. Freshw. Res. 2020, 55, 1-21. [CrossRef]

31. South, P.M.; Floerl, O.; Jeffs, A.G. The role of biofouling development in the loss of seed mussels in aquaculture. Biofouling 2019, 35, 259-272. [CrossRef]

32. Delorme, N.J.; Biessy, L.; South, P.M.; Zamora, L.N.; Ragg, N.L.C.; Burritt, D.J. Stress-on-stress responses of a marine mussel (Perna canaliculus): Food limitation reduces the ability to cope with heat stress in juveniles. Mar. Ecol. Prog. Ser. 2020, 644, 105-117. [CrossRef]

33. Delorme, N.J.; Ragg, N.L.C.; Buritt, D.J. Stress and health in New Zealand's number one aquaculture export-The Greenshell ${ }^{\mathrm{TM}}$ mussel. World Aquac. 2019, 50, 46-49.

34. Delorme, N.J.; Venter, L.; Rolton, A.; Ericson, J.A. Integrating animal health and stress assessment tools using the green-lipped mussel Perna canaliculus as a case study. J. Shellfish Res. 2021, 40, 93-112. [CrossRef]

35. Menge, B.A.; Daley, B.A.; Sanford, E.; Dahlhoff, E.P.; Lubchenco, J. Mussel zonation in New Zealand: An integrative ecophysiological approach. Mar. Ecol. Prog. Ser. 2007, 345, 129-140. [CrossRef]

36. Alfaro, A.C.; McArdle, B.; Jeffs, A.G. Temporal patterns of arrival of beachcast green-lipped mussel (Perna canaliculus) spat harvested for aquaculture in New Zealand and its relationship with hydrodynamic and meteorological conditions. Aquaculture 2010, 302, 208-218. [CrossRef]

37. Dunphy, B.J.; Ruggiero, K.; Zamora, L.N.; Ragg, N.L.C. Metabolomic analysis of heat-hardening in adult green-lipped mussel (Perna canaliculus): A key role for succinic acid and the GABAergic synapse pathway. J. Therm. Biol. 2018, 74, 37-46. [CrossRef] [PubMed]

38. Powell, J.A.; Ragg, N.L.C.; Dunphy, B.J. Phenotypic biomarkers in selectively-bred families of the Greenshell ${ }^{\mathrm{TM}}$ mussel (Perna canaliculus): Anaerobic enzyme and shell gape behaviour as biomarkers of prolonged emersion tolerance. Aquaculture 2017, 479, 601-608. [CrossRef]

39. Webb, S.C.; Heasman, K.G. Evaluation of fast green uptake as a simple fitness test for spat of Perna canaliculus (Gmelin, 1791). Aquaculture 2006, 252, 305-316. [CrossRef]

40. Nguyen, T.V.; Ragg, N.L.C.; Alfaro, A.C.; Zamora, L.N. Physiological stress associated with mechanical harvesting and transport of cultured mussels (Perna canaliculus): A metabolomics approach. Aquaculture 2020, 529, 735657. [CrossRef]

41. Marsden, I.D.; Weatherhead, M.A. Effects of aerial exposure on oxygen consumption by the New Zealand mussel Perna canaliculus (Gmelin, 1791) from an intertidal habitat. J. Exp. Mar. Biol. Ecol. 1998, 230, 15-29. [CrossRef]

42. Hermes-Lima, M.; Moreira, D.C.; Rivera-Ingraham, G.A.; Giraud-Billoud, M.; Genaro-Mattos, T.C.; Campos, É.G. Preparation for oxidative stress under hypoxia and metabolic depression: Revisiting the proposal two decades later. Free Radic. Biol. Med. 2015, 89, 1122-1143. [CrossRef]

43. Freire, C.A.; Welker, A.F.; Storey, J.M.; Storey, K.B.; Hermes-Lima, M. Oxidative stress in estuarine and intertidal environments (temperate and tropical). In Oxidative Stress in Aquatic Ecosystems; Abele, D., Vázquez-Medina, J.P., Zenteno-Savín, T., Eds.; Wiley-Blackwell: Chichester, UK, 2012; pp. 41-57.

44. Moreira, D.C.; Venancio, L.P.R.; Sabino, M.A.C.T.; Hermes-Lima, M. How widespread is preparation for oxidative stress in the animal kingdom? Comp. Biochem. Physiol. Part A 2016, 200, 64-78. [CrossRef]

45. Philipp, E.E.R.; Lipinski, S.; Rast, J.; Rosenstiel, P. Immune defense of marine invertebrates: The role of reactive oxygen and nitrogen species. In Oxidative Stress in Aquatic Ecosystems; Abele, D., Vázquez-Medina, J.P., Zenteno-Savín, T., Eds.; WileyBlackwell: Chichester, UK; Malden, MA, USA, 2012; pp. 236-246.

46. Cubillos, V.; Chaparro, O.; Segura, C.; Montory, J.; Cruces, E.; Burritt, D. Isolation-hypoxia and re-oxygenation of the pallial cavity of female Crepipatella dilatata during estuarine salinity changes requires increased glyoxylase activity and antioxidant metabolism to avoid oxidative damage to female tissues and developing embryos. Mar. Environ. Res. 2016, 119, 59-71.

47. Ivanina, A.V.; Sokolova, I.M. Effects of intermittent hypoxia on oxidative stress and protein degradation in molluscan mitochondria. J. Exp. Biol. 2016, 219, 3794-3802. [CrossRef] [PubMed]

48. Nogueira, L.; Mello, D.F.; Trevisan, R.; Garcia, D.; da Silva Acosta, D.; Dafre, A.L.; de Almeida, E.A. Hypoxia effects on oxidative stress and immunocompetence biomarkers in the mussel Perna perna (Mytilidae, Bivalvia). Mar. Environ. Res. 2017, 126, 109-115. [CrossRef]

49. Duan, Y.; Zhang, J.; Dong, H.; Wang, Y.; Liu, Q.; Li, H. Effect of desiccation and resubmersion on the oxidative stress response of the kuruma shrimp Marsupenaeus japonicus. Fish Shellfish. Immunol. 2016, 49, 91-99. [CrossRef] [PubMed]

50. Hou, S.; Jin, Z.; Jiang, W.; Chi, L.; Xia, B.; Chen, J. Physiological and immunological responses of sea cucumber Apostichopus japonicus during desiccation and subsequent resubmersion. Peer] 2019, 7, e7427. [CrossRef] [PubMed] 
51. Schvezov, N.; Lovrich, G.A.; Romero, M.C. Oxidatide stress during re-immersion of the king crab Lithodes santolla (Molina, 1782) (Decapoda: Anomura: Lithodidae) after air exposure. J. Crustacean Biol. 2017, 37, 195-203. [CrossRef]

52. Heasman, K. Temperature and Humidity of Kaitaia Weed during Harvesting, Storage and Transport and Suggested Influences on Spat Viability. Prepared for Marine Farmers Association; Cawthron Report No. 2428; Cawthron Institute: Nelson, New Zealand, 2013; p. 18.

53. South, P.M.; Delorme, N.J.; Skelton, B.M.; Floerl, O.; Jeffs, A.G. The loss of seed mussels in longline aquaculture. Rev. Aquac. 2021. [CrossRef]

54. South, P.M.; Floerl, O.; Jeffs, A.G. Magnitude and timing of seed losses in mussel (Perna canaliculus) aquaculture. Aquaculture 2020, 515, 734528. [CrossRef]

55. Hayden, B.J.; Woods, C.M.C. Effect of water velocity on growth and retention of cultured Greenshell ${ }^{\mathrm{TM}}$ mussel spat, Perna canaliculus (Gmelin, 1791). Aquac. Int. 2011, 19, 957-971. [CrossRef]

56. Skelton, B.M.; Jeffs, A.G. The loss of spat following seeding onto coastal Greenshell ${ }^{\mathrm{TM}}$ mussel (Perna canaliculus) farms. Aquaculture 2021, 544, 737115. [CrossRef]

57. Sorte, C.J.; Bernatchez, G.; Mislan, K.; Pandori, L.L.; Silbiger, N.J.; Wallingford, P.D. Thermal tolerance limits as indicators of current and future intertidal zonation patterns in a diverse mussel guild. Mar. Biol. 2019, 166, 1-13. [CrossRef]

58. Dunphy, B.J.; Ragg, N.L.C.; Collings, M.G. Latitudinal comparison of thermotolerance and HSP70 production in F2 larvae of the greenshell mussel (Perna canaliculus). J. Exp. Biol. 2013, 216, 1202-1209. [CrossRef]

59. Salinger, M.J.; Diamond, H.J.; Behrens, E.; Fernandez, D.; Fitzharris, B.B.; Herold, N.; Johnstone, P.; Kerckhoffs, H.; Mullan, A.B.; Parker, A.K. Unparalleled coupled ocean-atmosphere summer heatwaves in the New Zealand region: Drivers, mechanisms and impacts. Clim. Chang. 2020, 162, 485-506. [CrossRef]

60. Fryer, H.J.L.; Davis, G.E.; Manthorpe, M.; Varon, S. Lowry protein assay using an automatic microtiter plate spectrophotometer. Anal. Biochem. 1986, 153, 262-266. [CrossRef]

61. Reznick, A.Z.; Packer, L. Oxidative damage to proteins: Spectrophotometric method for carbonyl assay. Methods Enzymol. 1994, 233, 357-363.

62. Mihaljevic, B.; Katusin-Razem, B.; Razem, D. The reevaluation of the ferric thiocyanate assay for lipid hydroperoxides with special considerations of the mechanistic aspects of the response. Free Radic. Biol. Med. 1996, 21, 53-63. [CrossRef]

63. Maral, J.; Puget, K.; Michelson, A.M. Comparative study of superoxide dismutase, catalase and glutathione peroxidase levels in erythrocytes of different animals. Biochem. Biophys. Res. Commun. 1977, 77, 1525-1535. [CrossRef]

64. Janssens, B.J.; Childress, J.J.; Baguet, F.; Rees, J.F. Reduced enzymatic antioxidative defense in deep-sea fish. J. Exp. Biol. 2000, 203, 3717-3725. [CrossRef] [PubMed]

65. Paglia, D.E.; Valentine, W.N. Studies on the quantitative and qualitative characterization of erythrocyte glutathione peroxidase. J. Lab. Clin. Med. 1967, 70, 158-169.

66. Cribb, A.E.; Leeder, J.S.; Spielberg, S.P. Use of a microplate reader in an assay of glutathione reductase using 5,5'-dithiobis(2nitrobenzoic acid). Anal. Biochem. 1989, 183, 195-196. [CrossRef]

67. Quinn, G.P.; Keough, M.J. Experimental Design and Data Analysis for Biologists; Cambridge University Press: Cambridge, UK, 2002.

68. Underwood, A.J. Experiments in Ecology: Their Logical Design and Interpretation Using Analysis of Variance; Cambridge University Press: Cambridge, UK, 1996. 